\section{Marine Geology}

Vol. 234, Issues 1-4 , 18 Dec. 2006, Pages 93-109

http://dx.doi.org/10.1016/j.margeo.2006.09.010

(c) 2006 Elsevier B.V. All rights reserved
Archimer, archive institutionnelle de l'Ifremer http://www.ifremer.fr/docelec/

\title{
Sand bodies at the shelf edge in the Gulf of Lions (Western Mediterranean): Deglacial history and modern processes
}

\author{
M.A. Bassetti ${ }^{a, b,}$, G. Jouet ${ }^{a},{ }^{b}$, F. Dufois ${ }^{c}$, d, S. Berné ${ }^{a}$, M. Rabineau ${ }^{b}$ and M. Taviani ${ }^{e}$ \\ a'GM-IFREMER BP70 29280 Plouzané, France \\ bUMR6538 Domaines océaniques, IUEM, 29280 Plouzané, France \\ ${ }^{\mathrm{C} E C-T P-I F R E M E R / B P ~ 70 / 29280 ~ P l o u z a n e ́, ~ F r a n c e ~}$ \\ 'IRSN, Base Ifremer, BP 330, 83507 La Seyne sur Mer Cedex, France \\ ISMAR-CNR, Via P. Gobetti, 101 Bologna, Italy \\ *: Corresponding author : mabasset@ifremer.fr
}

\begin{abstract}
:
The outer continental shelf of the Gulf of Lions is covered by thick, mainly regressive, sand deposits. A combination of seismic, sedimentological and geochronological methods allows us to demonstrate that a veneer of transgressive sand bodies, few $\mathrm{m}$ to less than $1 \mathrm{~m}$ thick, reworks these deposits. They take the form of sand ridges and transverse dunes that formed at different periods. In fact, the lowgradient outer shelf of the Gulf of Lions displays a complete record of deglacial history, including not only transgressive deposits that formed during sea-level rise, but also bedforms that still evolve under episodic high-energy events that occur under more highstand conditions.
\end{abstract}

Core lithology, $14 \mathrm{C}$ dates and regional sea-level curve suggest that the formation of the sand ridges was favoured during a period of deceleration of sea-level rise, such as during the Younger Dryas event. The dunes are part of a "mobile carpet" (here U160). The deposition of this marine sand veneer is possibly related to the interplay between different factors that trigger the turning on/off for bottom currents sand deposition/transport on the outer shelf. In fact, the sands appear to have been reworked intermittently due to high-energy conditions in shallow water depth (currents, wave regime and winddriven circulation) as well as they form current ridges superimposed to the transgressive deposits in the westernmost part of the studied area (at the Bourcart Canyon's head).

Keywords: sand ridges; outer shelf; deglacial transgression; sand transport; Gulf of Lions 


\section{Introduction}

Background: "Offshore sands” of outer continental shelves

The concept of relict “offshore sands” was first introduced by Emery (1968), who observed that sand belts were covering many continental shelves around the world, at water depths generally comprised between 80 and $120 \mathrm{~m}$ water depth. He noticed that they were not in equilibrium with modern shelf processes, and concluded that these deposits were deposited during and immediately after the Last Glacial period. Later, Swift et al. (1971) suggested that shelf sands, although too coarse to have been transported by present-day processes, are being reworked and resorted by waves and currents, and referred to them as "palimpsest".

In the Gulf of Lions, which is considered as a relatively low energy continental shelf, most of the authors still consider that the offshore sands are relict features, only the transgressive processes, at a time when sea-level was lower by about $100 \mathrm{~m}$, being able to rework sediments (Aloïsi, 1986; Berné et al., 1998; Monaco, 1971). However, ultra-high resolution seismic data, coring and ${ }^{14} \mathrm{C}$ dating, as well as numerical modelling of wind stress on oceanic circulation, allow us to demonstrate that a mobile carpet of sand is periodically active at the shelf edge, feeding slope and rise deposits and contributing to the episodic reworking of shelf morphology.

Among the studies dedicated to the stratigraphy of the late Pleistocene in the Gulf of Lions (Monaco, 1971; Aloïsi 1986; Tesson et al., 1990; Rabineau et. al., 1998; Tesson et al., 2000; Rabineau, 2001; Berné et al., 2004, among the others), the present work concerns the definition of the post-glacial deposit geometry, as well as the distribution of sediments in relation with the latest Quaternary episodes and, in some cases, recent oceanographic events. As a matter of fact, we think that the most recent sedimentary unit is still under the influence of events able to mobilize at least the upper part of the well definable transgressive deposits. These consideration arise from the recently acquired data in the Gulf of Lions about the significant influence of cold water downwelling during winter storms on recent sedimentations (Palanques et al., 2004). In fact, seasonal modifications in the thermohaline circulation in the Gulf of Lions related to the wind action (Cers, Mistral and Tramontane wind complex) have been observed and we propose that the combination of regional interannual variability in water circulation and local hydrodynamic conditions (wind and wave-driven circulation) might lead to strong sea-bed stirring up and sediment transport. 
In order to support this hypothesis and, therefore, to estimate the degree of preservation of the most recent sedimentation layer, a numerical model of bottom shear-stress, is here proposed.

On the other hand, the post-glacial unit interfaces are closely analyzed, combining sedimentological data (sedimentary facies and fossil content), radiocarbon dates and seismic features, to trace them on the basis of their distribution on the basal ravinement surface.

\section{Regional and stratigraphic setting}

The Gulf of Lions is a passive, prograding margin, located in the northwestern sector of the Mediterranean Sea bounded, to the west and east, by Pyrenean and Alpine orogenic belts, respectively. It comprises a wide (at least $70 \mathrm{~km}$ ) shelf and a continental slope that is incised by numerous canyons descending down to the abyssal area of the Algero-Balearic Basin (Fig.1A). This basin formed as a result of Oligocene-Miocene rifting (Gorini et al., 1994) and it hosted the accumulation of huge amount of clastic sediments forming a thick wedge (900 m on the inner shelf, more than $2 \mathrm{~km}$ on the outer shelf (Lofi, 2002) that makes up the outbuilding shelf.

The post-rift sedimentation was severely affected by the Messinian Salinity Crisis (Hsü et al. 1973), when the sea level dramatically dropped (Ryan, 1976) and the continental margins were exposed to intense erosion (Cita and Ryan, 1978). The Messinian unconformity bases the cyclically stacked Plio-quaternary bodies that have been object of investigation over the last 30 years by several authors that proposed a number of stratigraphic models (Monaco, 1971; Aloïsi 1986; Tesson et al., 1990; Tesson et al, 2000; Rabineau, 2001, Lofi et al., 2003, Lobo et al., 2004). The last ca 500 kyr, in particular, display superimposed prograding wedges extending over the entire shelf seawards-thickening and pinching out landward beneath the $80 \mathrm{~m}$ isobath (Aloïsi, 1986). They are interpreted as deposited during 'forced regressions', in response to successive sea-level falls (Posamantier et al., 1992). They correspond to units U140, 147 and 150 in Fig. 2 (Berné et al., 1998; Rabineau et al., 1998; Rabineau et al., 2005).

The deglacial (post- Last Glacial Maximum) succession overlies the major erosional discontinuity related to emersion of the continental shelf during the Last Glacial Maximum (LGM). It consists of basal transgressive deposits, subsequently reworked, on the outer shelf, into dunes and sand ridges (U155; Berné et al., 1998; Rabineau, 2001, Perez-Belmonte, 2003) overlaining the regressive prograding body. It thickens toward the inner shelf, especially on the Rhône prodeltaic area, between 35 and 70 m water depth (Aloïsi, 1986; 
Gensous and Tesson, 2003; Berné et al., 2004). The shelf “relict” sands, whose distribution is shown in Fig.1A, were deposited from $80 \mathrm{~m}$ to about $120 \mathrm{~m}$ water depth, where they pass rapidly to marine muds. These sands were first described by Bourcart (1945) who called them "sables du large", an equivalent to the "offshore sands" of Emery (1968). The transition between sands and muds is outlined by a distinct regional step in the sea-floor morphology, that can reach up to 20-25 m of height and can be tracked all along the shelf edge (Berné et al., 2002). The sands are characterized by high carbonate content (25-50\%), mainly due to a significant biogenic component (Got and Aloïsi, 1990);

\section{Hydrodynamic setting}

The continental shelf of the Gulf of Lions is a low-energy wave dominated area where tides have small amplitudes (a few $\mathrm{cm}$ ) and associated currents are so weak that they cannot be measured (Lamy et al, 1981).

The general circulation and hydrodynamic conditions result from the interaction with the atmospheric phenomena, determining the formation of dense water, up- and downwellings and oscillatory currents caused by winds (Tramontane, Mistral) and storms (Millot, 1990).

One of the main components of the general circulation in the western Mediterranean is the “Liguro-Provençal-Catalan Current” or "Northern Current” which involves water of Atlantic origin, flowing southwestwards mainly along the continental slope and shelf break, following the continental margin. This current is characterized by speeds ranging from $50 \mathrm{~cm} \mathrm{~s}^{-1}$ near the surface and a few $\mathrm{cm} \mathrm{s}^{-1}$ at a few hundreds of metres depth (Monaco et al., 1990). According to Millot (1990), the core of the Northern Current follows the continental slope most of the time, but the trajectory can be temporally altered during northwesterly wind, when the superficial waters tend to penetrate onto the continental shelf forming a current front that can reach $30 \mathrm{~cm} \mathrm{~s}^{-1}$ after the wind decay (Millot and Wald, 1980). The hydrodynamic conditions on the continental shelf have a strong seasonal variability and the maximum current velocity is reached in winter (Millot, 1990, Estournel et al., 2003; Dufau et al., 2004).

An important parameter in the Gulf of Lions circulation is the meteorological forcing. In fact, local hydrodynamic conditions are determined by the interactions of wave regimes and winddriven circulation. The latter is generally dominated by the north-west Tramontane, or by the occurrence of Mistral and Tramontane winds that generate classical oceanographic features (up and downwellings, Palanques et al., this volume) and transitional circulation features 
such as inertial oscillations (Millot, 1990, Petrenko 2003). However, the winds are not homogeneous throughout the Gulf and especially easterly winds seem to generate the most significant bottom stress, according the modelling, year 2001 (Fig. 3A), despite their occasional occurrence (Fig. 3B). In fact, the surface wind stress, which occurs as individual storm events lasting several days, can generate bottom currents able to transport sediment. This has been demonstrated by in situ measurements on other continental shelves (Nittrouer and Wright, 1994; Drake, 1976; Drake and Cacchione, 1989), as well as studies on the genesis of Holocene sand banks (East Texas, Rodriguez et al., 1999, Snedden and Darlymple, 1999).

Nonetheless, extensive measurements of real current speeds at the bottom and its influence on sediment transport are not yet available in the Gulf of Lions. Recent studies demonstrate the existence of strong links between the occurrence of catastrophic meteorological events (such as winter storms) and the formation of cold, dense water cascading that reinforces the transport of suspended sediments and may trigger the remobilization of recent deposits from the shelf towards the canyons (Palanques et al., this volume). On the other hand, the wave influence on the outer shelf can be neglected, since it results to be not particularly significant in bottom shear stress generation mechanisms (Ulses, 2005).

In this work, we will focus on an area of the outer shelf and shelf edge, in the vicinity of the Bourcart canyon (Fig. 1).

\section{Methods}

The data were acquired during several cruises with R/V "Georges Petit”, "L’Europe”, "Le Suroît", "Beautemps-Beaupré" and "Marion Dufresne”. During these cruises, we used several high resolution seismic sources including (a) a 700 Joules SIG sparker, (b) a towed "EDO Western” 2.5kHz sub-bottom profiler, and (c) an hull-mounted "Eramer" Chirp system. Swath bathymetry systems included a Simrad EM 1000 (on “L’Europe”), EM300 (on "Le Suroît") and an EM 1002S on the "Beautemps Beaupré”. Cores were sampled with piston corers, vibro-corers, and the "Calypso" system onboard "Marion Dufresne". Radiocarbon dates were performed on selected shells (Table 1) using both conventional radiocarbon method and accelerator mass spectrometer (AMS). The shells were collected from various part in the listed cores. Well preserved material have been chosen (as bivalves with the two valves). 
All ${ }^{14} \mathrm{C}$ dates are given in calibrated ages, using the Cal v5.1 version (Hughen et al., 2004) or the polynomial in Bard et al. 1998, except for dates giving an age $>40.000$ years.

A correlation between the seismic units observed on very high resolution (700 Joules sparker) and ultra-high (chirp) seismic data and the post-glacial climatic/sea level changes was attempted. These data are "ground-truthed" by sedimentological interpretation of shallow cores (piston cores and vibra-cores), analysis of mollusc assemblages and ${ }^{14} \mathrm{C}$ dates. Seismic lines and core samples that are shown in this work are located in Fig. 1B.

The hydrodynamics was modelled using MARS-3D (André et al., 2005), a three-dimensional model in sigma co-ordinates, which solves equations under the assumptions of Boussinesq and hydrostaticity. It was designed to simulate the three components of the currents, surface elevation, temperature and salinity in coastal areas. The set of equation solved is well known and is given for example in Blumberg and Mellor (1987).

The model is forced by several parameters: atmospheric conditions (wind, solar fluxes...), river discharges, lateral fluxes and elevation at the open boundaries. The latter allows forcing the model with large-scale circulation such as the Northern Current.

In order to estimate the erosion probability, the most interesting output of the model is the bottom shear stress $(\tau)$ that is calculated under the assumption that velocity profile is logarithmic in the turbulent bottom layer (eq.1)

$$
\tau=\rho *[\kappa u(z) / \operatorname{Ln}(\mathrm{z} / \mathrm{z} 0)]^{2}
$$

(eq. 1), where $\rho$ is the water density, $\kappa$ the von Karman constant (0.4), and z0 the roughness length of bed surface taken as $0.0035 \mathrm{~m}$.

The observations of simulated bottom shear stress for all the 2001-year show that easterly winds have the strongest effect on bottom stress, generated in the western part of the shelf after a few hours. Therefore, a simulation with a constant wind of $20 \mathrm{~m} / \mathrm{s}$ from the east for the entire area of Gulf of Lions, has been run to determine bottom stress during high easterly wind events (wind directions seems to be more significant than wind intensity to force bottom circulation in this area, Fig. 3A). Consequently, in this work, we do not consider the influence of N-NW winds since the bottom shear stress generated by these winds is estimated not strong enough for remobilizing sandy sediments.

\section{Results}

Morphology and seismic facies of post-glacial deposits

(a) Sand ridges- In the studied area, the major morphological feature is represented by the sand ridges, localized between 95 and 110 m water depth (U155). They have limited areal 
distribution, variable heights (up to $9 \mathrm{~m}$ ) a mainly WNW-ESE orientation, as recognized on the bathymetric maps (Fig. 4A). They have an irregular topography and mainly show a linear, elongated shape. On the chirp profiles their surface is smooth, they form bodies of maximum length of $5 \mathrm{~km}$ and they rest on a major erosional surface (ravinement surface) that is possibly exposed beyond the ridge field (Fig. 5A). The ridges have an asymmetric transverse profile (with the steepest slope facing the SW). At times, they show a nearly symmetric profile, but it concerns only the smaller bodies. They show distinct clinoforms, dipping in the SW direction (Fig. 2 and 4C) and some chaotic internal reflections (Fig.5B), probably in relation with coarse-grained material diffracting seismic waves. However, some major erosional surfaces (discontinuities) can be recognized within the ridge, that may be related to storm events affecting the ridge growth, although they cannot be correlated from one ridge to another. These sand ridges correspond to seismic unit U155.

(b) the dunes were only detected when we used high-resolution swath bathymetric systems, such as the EM 1000 and EM1002S (Fig. 4B). They have an average spacing of $130 \mathrm{~m}$ and maximum height of $2 \mathrm{~m}$. Their great axis has a NNW-SSE orientation in the NE part of the surveyed area, turning progressively to NW-SE in the SW corner (Fig. 4B). Their internal structure was not detectable considering their small size. They are classified as transverse dunes in the sense of Ashley (1990) and they clearly rework the shape of the sand ridges.

On top of the sand ridges, chirp and sub-bottom seismic profiles display a thick pattern of parallel reflections, that was first considered as the result of some ringing effect representing the pulse length of the seismic sources, instead of a real sedimentary layer. However, extensive coring (see next section) and bathymetric data (Fig. 4B) demonstrated that a distinct layer actually exists at the sea-floor interface. All together, the dunes and the uppermost layers will be included into a new seismic unit named U160.

\section{Sedimentary facies}

Units U155 and U160 have been extensively sampled by vibrocoring and piston coring. The various sedimentary facies can be classified into three main types: (1) muddy sand facies, (2) sand facies and (3) gravel facies (Fig. 6).

The muddy sands (from medium to coarse grained) generally consists of a maximum of $2 \mathrm{~m}$ thick veneer of sediments (U160) covering U155. They are homogeneous and possibly bioturbated. They do not show bedding and contain abundant biogenic sand often concentrated into irregular layers. 
The sand facies does not show any structure and consists of sand (rarely muddy sand) with or without shells or shell beds. The sand facies comprises the sand ridges (U155), the sediments are medium to coarse-grained and moderately to well-sorted. The sand is dominantly siliciclastic with a minor amount of biogenic components (mollusc shell fragments). The shells that are found there are indicative of nearshore, shallow-water environment of a 10-100 m water range. Presence of reworked material is highly possible in this facies.

The gravel facies marks a sharp lithological passage with the underlying deposits, it consists of mixed clasts and biogenic fragments, often in a muddy matrix. The macrofaunal assemblage of this facies is prevalently a mixture of mollusc shells sourced from littoralestuarine (Mytilus sp.) to infralittoral nearshore environments associated with bioturbationdriven younger shells from deeper environments. These shell assemblages contain typical cold guests (Arctica islandica, Mya truncata, Buccinum sp), likely indicating the latest glacial age (Fig.6). In fact, the gravel facies is usually found at the transition between units U150 and U155, therefore it corresponds to the erosional surface that bases the post-glacial deposits (ravinement). The lithological passage between unit U155 and the underlying forced regressive bodies is always abrupt and easily detectable both on seismic profiles and on core sections (Figs. 5A-B, 6).

\section{Chrono-stratigraphic constraints}

Based on the numerous ${ }^{14} \mathrm{C}$ dates, it is possible to distinguish 2 groups of dates belonging to deposits that are separated by the ravinement surface situated between U155 and U150, despite the fact that some shells are likely reworked from older deposits. Under this surface, the forced regressive deposits of U150 are all dated more than $20 \mathrm{ka}$ cal BP. Above it, the dates within U155 range from 15 ka to $12 \mathrm{ka}$ cal BP. The uppermost U160 layer displays a very broad range of ages, from early Holocene (about $10 \mathrm{kyr}$ cal BP) to recent (250 yr cal BP). The presence of a "modern" shell (1682 yr cal BP, core 93C4 in Fig. 6) at $145 \mathrm{~cm}$ below the sea-floor demonstrates the high amount of mobility of unit U160. In order to understand the processes at the origin of the mobility of U160, we utilized the output of the Mars 3D circulation model of the Gulf of Lions.

\section{Wind-induced bottom circulation}

Based on the statistical analysis of Fig. 3, the easterly winds are likely the source of high shear stress in our study area. Therefore, we used a realistic constant wind velocity of $20 \mathrm{~m} / \mathrm{s}$, 
blowing during a period of 7 days, in order to evaluate the effect on the sea-floor. It turns out that, after one day, intense bottom currents can be produced in the coastal zone, as expected, but also in the westernmost area of the shelf and at the shelf break (Fig. 8A). The maximum effect, occurring at the beginning of the events and showing tensions up to $0,24 \mathrm{Nm}^{-2}$ at the sea-bottom, can be expected at about $100 \mathrm{~m}$ depth. The observation of the bottom currents evolution during several days demonstrates that the tensions progressively weakens during a 7-day period, and that the area where the bottom shear stress is the most intense progressively moves southwestwardly (Fig. 8B). The reason of this south-westward shifting is not clear: it could be related to a local acceleration of the flow due to a convergence of the shelf water transport towards the SW ends of the gulf. In summary, one single day of constant wind blowing at $20 \mathrm{~m} / \mathrm{s}$ is sufficient for erosion and transport in the SW direction of fine sand in our study area. This direction is consistent with that predicted from the asymmetry of transverse dunes. More precisely, it might be noted that the progressive change in direction of transverse dunes observed on the swath bathymetric map of Fig. 4 coincide with the progressive shift of predicted directions of sand transport from WSW to SW in Fig. 8. Compared to this very conservative $20 \mathrm{~m} / \mathrm{s}$ scenario, there is no doubt that much more severe meteorological conditions that likely occurred during the last hundred years, allowed episodic transport of all classes of sand and rejuvenation of transverse dunes, which therefore can be considered as "active”.

\section{Discussion}

Bounding surfaces associated with transgressive deposits

Our investigation demonstrates that, on the outer shelf, the transgressive deposits only consist of a thin veneer ( 0 to $9 \mathrm{~m}$ thick) of sandy sediment resting on a marine ravinement surface. These transgressive deposits rework the sandy facies that formed between Marine Isotope Stage (MIS) 3 and the Last Glacial Maximum. The shoreface sands form a thick (up to $30 \mathrm{~m}$ ) regressive wedge that was mis-interpreted by some authors as a transgressive parasequence (Gensous and Tesson, 1997). In fact, the top of regressive deposits were reworked into transgressive dunes and ridges during the deglacial sea-level rise (Fig. 9), making difficult the seismic and lithological distinction of the two units. However, the base of the transgressive deposits is clearly detectable on ultra-high resolution seismic profiles (Fig. 5). In addition, ${ }^{14} \mathrm{C}$ dates, despites some age inversions due to reworking, allow to distinguish transgressive (<16 ka cal BP) and regressive deposits (45 to $20 \mathrm{ka}$ cal BP). In between, timetransgressive erosional (or ravinement) surface made of coarse sand with abundant shells and 
shell fragments are observed. Similar erosional surfaces are reported in many continental shelves such as the Adriatic sea (Trincardi et al., 1994) or the Gulf of Mexico (Anderson et al., 2004). However, because a relatively high energy situation compared to the abovementioned areas, the surface are more distinct in the Gulf of Lions.

\section{Sand ridges formation and implications for sea level reconstruction}

Active, "moribund" and relict sand ridges are described over most continental shelves around the world. If we have clear evidences for proposing that transverse dunes are still episodically actives, it is difficult to determine what is the status of sand ridges. However, according to some authors (see review by Berné, 2002) their spacing is an indirect way to estimate paleo-water depths at which they were created. Different equations have been proposed that link bedform spacing and water depth:

(1) $\mathrm{H}=0.167 \mathrm{~h}$ (Yalin, 1964)

(2) $\mathrm{H}=0.086 \mathrm{~h}^{1.19}$ (Allen, 1984)

Where $\mathrm{H}$ is the dune height and $\mathrm{h}$ is the water depth. With both equations, we obtain a maximum water depth of about $50 \mathrm{~m}$ for ridge formation. Considering that present water depth of these features is between 95 and $110 \mathrm{~m}$, and using a sea-level curve as that of Fig. 9, it gives an age of 11 to $12 \mathrm{ka} \mathrm{Cal} \mathrm{BP,} \mathrm{at} \mathrm{least,} \mathrm{for} \mathrm{ridge} \mathrm{formation} \mathrm{that} \mathrm{may} \mathrm{correspond} \mathrm{to} \mathrm{the}$ Younger Dryas event. During this period, sea-level rise deceleration or a short-lived stillstand possibly favoured the formation of these sedimentary bodies. This age is consistent with most of the ${ }^{14} \mathrm{C}$ dates found within unit U155.

Additional support to the estimated shallow water nature of the sand ridges may be derived from the macrofaunal assemblage indicating a 3-50 m depth range. In particular, within this unit (155) the basal erosional surface (ravinement) contain shells unquestionably sourced from littoral-estuarine (i.e Mytilus cf galloprovincialis) to infralittoral-nearshore environments, while those hosted in the ridges muddy sand suggest a deeper sub-littoral environment in the order of 30-50 m approximately.

On the other hand, macrofaunal assemblages of unit 160 are enriched in benthic bivalves (Bathyarca grenophia, Nuculana commutata, Pseudoamussium clavatum, Corbula gibba, Timoclea ovata...), gastropods (Aporrhais cf. pespelecani, Turritella communis, Alvania testae etc.), scaphopods (Dentalium sp.) and occasional holoplanktic thecosomatous pteropods (Creseis acicula, Diacria trispinosa), characterizing macrofaunal communities inhabiting offshore middle to outer shelf setting, from $50 \mathrm{~m}$ down, thus supporting the interpretation of a “modern” bed. 
The best estimate for the age of the ravinement surface in our study area comes from core MD992351, where a shell of Mytilus sp. yield an age of 15947 a cal B.P. The corresponding water depth is $98+1=99 \mathrm{~m}$ (Fig.6 and 9).

\section{Sediment transport during late Holocene and modern oceanographic conditions}

Sediment deposition on the shelf is related to the sediment input from land, topography of the sea floor and wave and current energy. For those sediments, subsequent transport can result from processes linked to occasional events.

In the Gulf of Lions, numerical modelling shows that oceanographic and meteorological processes can combine to generate ample bed shear stresses to move fine sands. Windinduced tensions during extreme meteorological conditions are capable of reaching the sea floor at the outer shelf depth (100 m approximately), producing currents that have an erosive potential and possibly producing bottom stresses triggering sediment transport on- and offshore, in particular down the submarine canyons.

A distinctive feature associated with the Gulf of Lions setting resulting from the modelling is that of shear bed stresses are mainly generated in the area where dunes are found (western outer shelf), whereas the flat mid shelf is weakly affected by the wind-induced bottom tensions.

This fact suggests that during extreme meteorological events linked to easterly winds (as showed in the model, Fig.8), the flow jetting is bypassing the mid shelf where the bottom shear stress is $<0,1 \mathrm{~N} \mathrm{~m}^{-1}$, whereas, according to the model, bathymetric influence induces a rapid increase of bottom shear stress up to $0.24 \mathrm{~N} \mathrm{~m}^{-1}$ toward the SW outer shelf area. The proposed mechanism would imply a large remobilization of at least the uppermost sediment layer that blankets the outer shelf and this is actually the area where the draping unit 160 is detected on the high resolution seismic profiles.

\section{Conclusions}

The correlation between the seismic units defined on the outer shelf, the numerous sediment cores, and the sea-level curve allows us to establish a scenario for the evolution of shelf edge sand bodies (Fig. 9):

1. during the LGM sea level lowstand, the platform underwent intensive erosion and, at the onset of deglaciation, the landward migration of shoreline activated the deposition of a transgressive unit, based by a ravinement surface that can be followed throughout the whole outer shelf. Such a discontinuity is unambiguously recognized on the basis 
of characteristic seismic and lithological features and ${ }^{14} \mathrm{C}$ dates. This surface is dated at $15900 \mathrm{y}$ cal BP at $99 \mathrm{~m}$ water depth;

2. the transgressive deposits take form of sand ridges that cover a portion of the outer shelf (U155). They usually show asymmetric transverse profiles (with a lee side toward SW). ${ }^{14} \mathrm{C}$ dates, core lithology and inferences from the depth of formation of modern sand ridges, suggest that they formed during a slow down of sea-level rise, around the Younger Dryas;

3. these transgresssive deposits are toped by a thin $(<2 \mathrm{~m})$ layer of sands or muddy sands (here called U160) that blankets the outer shelf, sometimes shaped into transverse dunes. Numerical modelling demonstrates that easterly winds can be at the origin of sea-floor shear stress sufficient for sand transport, in our study area as well as in the Western Gulf of Lions (where larger dunes are also observed). Therefore, these bedforms can be considered as "active" features.

4. The occurrence of strong energy events able to remobilize and transport sand from former shoreface deposits situated at the shelf edge is a mechanism for supplying sand to canyon heads, as observed by Gaudin et al. (this volume). This mechanism, and others such as dense water cascading Palanques et al., this volume; Ulses, 2005), can be the source of sand to the deep-sea during modern (highstand) conditions.

\section{Acknowledgments}

This research is supported by the European Community through the Eurostrataform (contract EVK3-2001-00200) and Promess 1 (contract EVR1-CT-2002-40024) projects. Additional support came from Ifremer, "Region Languedoc-Roussillon" and the French "Margins" program. US partners are supported by Office of Naval Research. The French Hydrographic Service (SHOM) gave access to sounding charts. Special thanks are due to Yann Stephan and Gwladys Theuillon who gave access to recently acquired (2004) swath bathymetric data with "Beautemps Beaupré", in the framework of the "Calimero" project (convention 8D/003 between SHOM and Ifremer) as well as Xavier Lurton at Ifremer. Captains and crews of "Marion Dufresne", "Le Suroît" and "L'Europe" are thanked during cruises "Basar" 1 and 2, "Calmar 99", "Strataform", GMO2 (thanks to N. Sultan), and "Beachmed" (thanks to C. Satra). Colleagues at Ifremer and Genavir (R. Apprioual, B. Dennielou, F. Duval, G. Floch, R. Kerbrat, E. Le Drezen, A.S. Alix, E. Leroux, L. Morvan, A. Normand, C. Prud'homme, D. Pierre), are warmly thanked for their assistance.

Moreover, we are indebted to prof. F.J. Hérnandez-Molina and to two anonymous reviewers 
for thorough revision and critical discussions.

This is IGM scientific contribution n. 1445 and n. 990 IUEM contribution.

\section{References}

Allen, J.R.L., 1984. Principles of Physical sedimentology, Allen and Unwin, London, 272 pp.

Aloïsi, J.-C., 1986. Sur un modèle de sédimentation deltaïque:Contribution à la connaissance des marges passives. PhD thesis, University of Perpignan, $162 \mathrm{pp}$.

Anderson, J.B., Rodriguez, A., Abdulah, K.C., Fillon, R.H., Banfield, L.A., McKeown, H.A. and Wellner, J.S., 2004. Late Quaternary Stratigraphic evolution of the northern Gulf of Mexico margin: a synthesis. In: J.B. Anderson and R.H. Fillon (Editors), Late Quaternary Stratigraphic evolution of the northern Gulf of Mexico margin. SEPM (Society for Sedimentary Geology), Tulsa, pp. 1-23.

André, G., Garreau P, Garnier V, Fraunie P., 2005. Modelled variability of the sea surface circulation in the North-western Mediterranean Sea and in the Gulf of Lions. Ocean Dynamics 55, 294-308.

Ashley, G.M., 1990. Classification of large-scale subaqueous bedforms : a new look at an old problem. Journal of Sedimentary Petrology, 60 (1), 160-172.

Bard, E., Arnold, M., Hamelin, B., Tisnerat-Laborde, N., Cabioch G., 1998, Radiocarbon calibration by means of mass spectrometric 230Th/234U and 14C ages of corals. An updated data base including samples from Barbados, Mururoa and Tahiti., Radiocarbon 40 (3), 10851092

Berné, S., 2002. Offshore sands. In: G.V. Middleton (Editor), Encyclopedia of Sediments and Sedimentary Rocks. Kluwer Academic Publishers, pp. 492-499.

Berné, S., Lericolais, G., Marsset, T., Bourillet, J.F., de Batist, M., 1998. Erosional shelf sand ridges and lowstand shorefaces. Examples from tide and wave dominated environments of France. Journal of Sedimentary Research 68 (4), 540-555.

Berné, S., Rabineau, M., Flores, J.A., Sierro F.J., 2004. The impact of Quaternary global changes on strata formation. Oceanography 17 (4), 92-103.

Berné, S., Satra, C., Aloïsi, J.C., Baztan, J., Dennielou, B., Droz, L., Dos Reis, A.T., Lofi, J., Méar, Y. and Rabineau, M., 2002. Carte morpho-bathymétrique du Golfe du Lion, notice explicative, Ifremer, Brest.

Blumberg, A.F., Mellor, G.L., 1987. A description of a three dimensional coastal circulation model. In: Heap, N.S. (Ed.), Three dimensional coastal ocean models, Coastal and Estuarine Sciences 4, American Geophysical Union, Washington, D.C., 1-16. 
Bourcart, J., 1945. Etude des sediments pliocènes et quaternaries du Roussillon: service Carte Géologique de France. Bullettin, 45, 395-476

Camoin, G.F., Montaggioni, L.F., Braithwhite, C.J.R., 2004. Late to post glacial sea levels in the Western Indian Ocean. Mar. Geol., 206, 119-146.

Cita, M.B., Ryan, W.B.F. (Eds.), 1978. Messinian erosional surfaces in the Mediterranean. Mar. Geol. 27, 193-365.

Drake, D.E., 1976. Suspended sediment transport and mud deposition on continental shelves. Marine Sediment Transport and Environmental Management, John Wiley and Sons, New York, 127-158.

Drake, D.E., Cacchione, D.A., 1989. Field observations of bed shear stress and sediment resuspension on continental shelves, Alaska and California. Continental Shelf Research 6, 415429.

Dufau, C., Marsaleix, P., Petrenko, A., Dekeyser, Y., 2004. 3D modeling of the Gulf of Lion's hydrodynamics during January 1999 (MOOGLI 3 experiment) and Late winter 1999 : WIW formation and cascading over the shelf break, Journal of Geophysical Research, 109 (C11), C11002, doi :10.1029/2003 JC 002019.

Emery, K.O., 1968. Relict sediments on continental shelves of the world. Bull. Am. Assoc. Petrol. Geol., 52, 445-464.

Estournel, C., Durrieu de Madron, X., Marsaleix, P., Auclair, A., Julliand-Dufau., C., Vehil, R., 2003. Observation and modelisation of the winter coastal oceanic circulation in the Gulf of Lions under wind conditions influenced by the continental orography (FETCH experiment), Journal of Geophysical Research, 108 (C3), 8059, doi : 10.1029/2001 JC 000825.

Fairbanks, R.G., 1989. A 17,00-year glacio-eustatic sea level record: influence of glacial melting rates on the Younger Dryas event and deep-ocean circulation. Nature, 342, 637-642.

Gaudin, M., Berné, S., Jouanneau, J-M., Palanques, A., Puig, P., Mulder, T., Cirac, P., Rabineau, M., Imbert, P. Massive sand beds deposited by dense water cascading in the Bourcart canyon head, Gulf of Lions (northwestern Mediteranean Sea). Marine Geology, this volume.

Gensous, B. and Tesson, M., 1997. Postglacial deposits of the Rhone shelf: stratigraphic organisation and growth patterns. Comptes Rendus de L'Académie des Sciences - Series IIA Earth and Planetary Science, 325(9), 695-701.

Gensous, B. and Tesson, M., 2003. L'analyse des dépôts postglaciaires et son application à l'étude des séquences de dépôt du Quaternaire terminal sur la plate-forme au large du Rhône (golfe du Lion). Bulletin de la Société Géologique de France, 174(3): 401-419. 
Gorini, C., Mauffret, P., Guennoc, P., Le Marrec, A., 1994. The structure of the Gulf of Lions (Northwestern Mediterranean Sea): a review. In: Mascle, A. (Ed.), Hydrocarbon and petroleum geology of France. Springer-Verlag, New York, pp. 223-243.

Got, H., Aloïsi, J.-C., 1990. The Holocene sedimentation on the Gulf of Lions margin: a quantitative approach. Cont. Shelf Res. 10 (9-11), 841-855.

Hughen, K.A., Baillie, M.G.L., Bard, E., Bayliss, A., Beck, J.W., Bertrand, C.J.H., Blackwell, P.G., Buck, C.E., Burr, G.S., Cutler, K.B., Damon, P.E., Edwards, R.L., Fairbanks, R.G., Friedrich, M., Guilderson, T.P., Kromer, B., McCormac, F.G., Manning, S.W., Bronk Ramsey, C., Reimer, P.J., Reimer, R.W., Remmele, S., Southon, J.R., Stuiver, M., Talamo, S., Taylor, F.W., van der Plicht, J., Weyhenmeyer, C.E. 2004. Marine04 Marine radiocarbon age calibration, 26 - 0 ka BP. Radiocarbon, 46,1059-1086

Hsü, K.J., Ryan, W.B.F., Cita M.B., 1973. Late Miocene desiccation of the Mediterranean. Nature 242, 240-244.

Lamy, A., Millot, C., Molines, J.M., 1981. Bottom pressure and sea-level measurements in the Gulf of Lions. Journal of Physical Oceanography 11, 394-410.

Lobo, F.J, Tesson, M., Gensous, B. 2004. Stratral architectures of late Quaternary regressivetransgressive cycles in the Roussillon Shelf (SW Gulf of Lions, France). Mar. Petrol. Geol., 21 (9), 1181-1203

Lofi, J., 2002. La crise de salinité messinienne: conséquences directes et différées sur l'évolution sédimentaire de la marge du Golfe du Lion, Lille 1, Lille, 260 pp.

Lofi, J., Rabineau, M., Gorini, C., Berne, S., Clauzon, G., De Clarens, P., Tadeu Dos Reis, A., Mountain, G.S., Ryan, W.B.F., Steckler, M.S. and Fouchet, C., 2003. Plio-Quaternary prograding clinoform wedges of the western Gulf of Lion continental margin (NW Mediterranean) after the Messinian Salinity Crisis. Marine Geology, 198(3-4), 289-317.

Millot, C., 1990. The Gulf of Lions’ hydrodynamics. Cont. Shelf Res. 10 (9-11), 885-894.

Millot, c., Wald, L., 1980. The effect of Mistral wind on the Ligurian Current near Provence. Oceanologica Acta 3, 399-402.

Monaco, A., 1971. Contribution à l'étude géeologique et sédimentologique du plateau continental du Roussillon. PhD thesis, Unveristy of Perpignan, pp. 295.

Monaco, A., Courp, T., Heussner, S., Carbonne, J., Fowler, S.W., Deniaux, B., 1990. Seasonality and composition of particulate fluxes during ECOMARGE-I, western Gulf of Lions. Cont. Shekf. Res., 9-11, 959-987.

Nittrouer, C.A., Wright, L.D., 1994. Transport of particles across the continental shelves. Rev. Geophys., 32, 85-113 
Perez-Belmonte, L., 2003. Enregistrement de la dernére transgression dans le Gulf du Lion. Memoire DEA,University of Lille, pp. 52.

Palanques, A., Durrieu de Madron, X., Puig, P., Fabres, J., Guillén, J., Calafat, A., Canals, M., Bonnin, J. Suspended sediment fluxes and transport processes in the Gulf of Lions submarine canyons. The role of storms and dense water cascading. Marine Geology, this volume.

Palanques, A., Puig, P., Durrieu de Madron, X., Guillén, J., Calafat, A., Fabrés, A., Bourrin, F., Heussner, S., Canals, M., 2004. Suspended sediment fluxes in the Gulf of Lion submarine canyons during the november-may 2003 high resolution experiment. Eurodelta-Eurostrataform meeting, Venice 2004, Abstr. Book, p.29.

Petrenko, A.A., 2003. Circulation feautures in the Gulf of Lions, NW Mediterranean Sea; importance of inertial currents. Oceanologica Acta, 26, 323-328.

Posamamtier, H.W., Allen, G.P., James, D.P., Tesson, 1992. Forced regression in a sequence stratigraphic framework: concepts, examples, and exploration significance. AAPG Bullettin 76, 1687-1709

Rabineau, M., Berné, S., Aslanian, D., Olivet, J-L., Joseph, P., Guillocheau, F., Bourillet, J.-F., Ledrezen, E., Granjeon, D., 2005. Sedimentary sequences in the Gulf of Lion: A record of 100,000 years climatic cycles. Mar. Petrol. Geol., 22(6-7), 775-804

Rabineau, M., 2001. Un modéle géométrique des sequences des dépôts quaternaires sur la marge du Gulf du Lion: enregistrement des cycles climatiques de 100.000 ans. PhD thesis, University of Rennes, pp. 394.

Rabineau, M., Berné, S., Ledrezen, E., Lericolais, G., Marsset, T., Rotunno, M., 1998. 3D architecture of lowstand and transgressive Quaternary sand bodies on the outer shelf of the Gulf of Lion, France. Marine and Petroleum Geology 15, 439-452.

Ryan, W.B.F., 1976. Quantitative evaluation of the depth of the Western Mediterranean before, during, and after the Late Miocene salinity crisis. Sedimentology 23, 791-813.

Rodriguez, A.B., J.B., Anderson, Siringan, F.P., Taviani, M., 1999. Sedimentary facies and genesis of Holocene sand banks on the East Texas inner continental shelf. In: Bergman, K.M. and Snedden, J.V. (Eds), Isolated Shallow Marine Sand Bodies: Sequence Stratigraphic Analysis and Sedimentologic Interpretation, SEPM, Spec. Publ. 64, pp. 165-178.

Snedden, J.W, Darlymple, R.W., 1999. Modern shelf sand ridges: from hystorical perspective to a unified hydrodynamic and evolutionary model. In: Bergman, K.M. and Snedden, J.V. (Eds), Isolated Shallow Marine Sand Bodies: Sequence Stratigraphic Analysis and Sedimentologic Interpretation, SEPM, Spec. Publ. 64, pp. 13-28. 
Soulsby, R.L., 1997, Dynamics of marine sands. A manual for practical applications. Thomas Telford Publications, 249 pp

Swift, D.J.P., Stanley, D.J., Curray, J.R., 1971. Relict sediments on continental shelves; a reconsideration. Journ. Of Geology, 79(3), 322-346.

Tesson, M., Gensous, B., Allen, G., Ravenne, C., 1990. Late Quaternary lowstand wedges on the Rhône continental shelf, France. Marine Geology, 91, 325-332.

Tesson, M., Posamentier, H.W. and Gensous, B., 2000. Stratigraphic organisation of Late Pleistocene deposits of the western part of the Rhone shelf (Languedoc shelf) from high resolution seismic and core data. AAPG Bulletin, 84(1): 119-150.

Trincardi, F., Correggiari, A., Roveri, M., 1994. Late Quaternary transgressive erosion and deposition in a modern epicontinental shelf: the Adriatic semi-enclosed basin. Geo-Mar. Lett. 14, 41-51.

Ulses, C., 2005. Dynamique océanique et transport de la matière dans le Golfed u Lion: crue, tempêtes et période hivernale. PhD Thesis, University Paul Sabatier, 247 pp.

Yalin, M.S., 1964. Geometrical properties of sand waves. Proc. Am. Soc. Civil Engrs., J. Hydraul. Div., 90, 105-119 


\section{Figures captions}

Fig.1: A) Bathymetric map of the Gulf of Lions and position of the study area on the outer shelf. LDC, Lacaze-Duthiers Canyon; PvC, Pruvot Canyon; BC/AC, Bourcart or Aude Canyon; HC, Herault Canyon; SC, Séte Canyon; MaC, Marti Canyon; PRC, Petit-Rhône Canyon; GRC, Grand- Rhône Canyon; EC, Estocade canyon; B) location of seismic lines and cores, showed in this study, at the head of Herault Canyon

Fig.2: Seismic section across the Pleistocene sand wedges (Bas 59 on Fig.1) showing the vertical relationship of the seismic unit identified on the outer shelf of the Gulf of Lions (from Berné et al., 1998, modified)

Fig.3: (A) Comparison plot of wind distribution and the bottom shear stress that they generate measured at a fix point (Long 3.9E; Lat. $42.9 \mathrm{~N}$ ). Remarkable difference is observed between the bottom stresses induced by easterly winds (up to $0,2 \mathrm{~N} / \mathrm{m}^{2}$ ) with respect to the ones linked to the Tramontane, Mistral, Cers wind complex, despite their lower occurrence in the gulf. Critical shear stress for sand $(300 \mu \mathrm{m})$ and coarse silt $(40 \mu \mathrm{m})$ transport is marked on the plot (after Soulsby, 1997). (B) Statistical record of wind annual (year 2001) and interannual occurrence (years 1994-2001) in the Gulf of Lions, based on the model Météo France ARPEGE. Note that the statistic probability of wind occurrence observed over several years is very similar to the one established during one single year.

Fig.4: Detailed morpho-bathymetric map of the study area: A) morphological alignments are evident on the general map corresponding to the transgressive deposits (dunes); B) closer view of the map of Fig.4A. Note the superimposition of dunes on fossil ridges, possibly linked to modern hydrodynamics. Data and processing by Service Hydrographique de la Marine (SHOM); C) Internal structure of a sand ridge (2.5 kHz subottom profile). Apparent WSW direction of migration is indicated by the dipping of clinoforms. The upper layers are not distinct at the resolution of the system, and create a thick packet of parallel reflections.

Fig.5: Uninterpreted and interpreted seismic profile sections located on the outer shelf (A) and at the shelf break (B), which clearly show the stratigraphic relations between the forced regressive bodies (U140, 147, 150), transgressive deposits (U155) and deglacial unit (U160). The two profiles are approximately perpendicular (see Fig. 1B). The boxes point to the closer view showed in Fig. 7 A-B-C

Fig.6: Time correlation along the BM05 (A) and BM02 (B), see Fig.1 for location. The time equivalency is based on ${ }^{14} \mathrm{C}$ dates, seismic features and facies analysis.

Fig.7: A) Uninterpreted and interpreted portion of the high resolution seismic profile BM05 showing the strongly lenticular geometry of unit 155 (transgressive sand ridges), draped by 
the modern mobile layer, as discussed in the text. Note the change in amplitude in the upper reflections, that supports the interpretation of a real upper mobile layer rather than a ringing effect of the seismic signal. The core MD 2350 is located at the lateral pinch out of the unit 155 (see Fig.6 for log and lateral correlation) and, possibly, the uppermost part of the core was lost during coring operations; B) landward thinning of units 155 and 160. However, there are no clear indications of the presence of the unit 160 on this area: tracing the U160 in this part of the shelf is mostly speculative and, possibly, the U155 is exposed at the sea bottom. In the figure $\mathbf{C}$, the $\mathrm{U} 160$ is more than $2 \mathrm{~m}$ thick, as also confirmed by the ${ }^{14} \mathrm{C}$ dates (see Fig. 6)

Fig.8: The intense winds from east can induce a significant bottom shear stress (according to the model MARS 3D) in the western part of the outer shelf that is stronger at the beginning of the wind event due to the contribution of inertial-gravity oscillation signal (A). On a longer time frame (1 week, in this model), the stress on the bottom gradually decreases in intensity (B)

Fig.9: Correlation of depositional events in the outer shelf of the Gulf of Lions during the last 20 ka to the global sea-level curve (from Camoin et al., 2004, modified) 

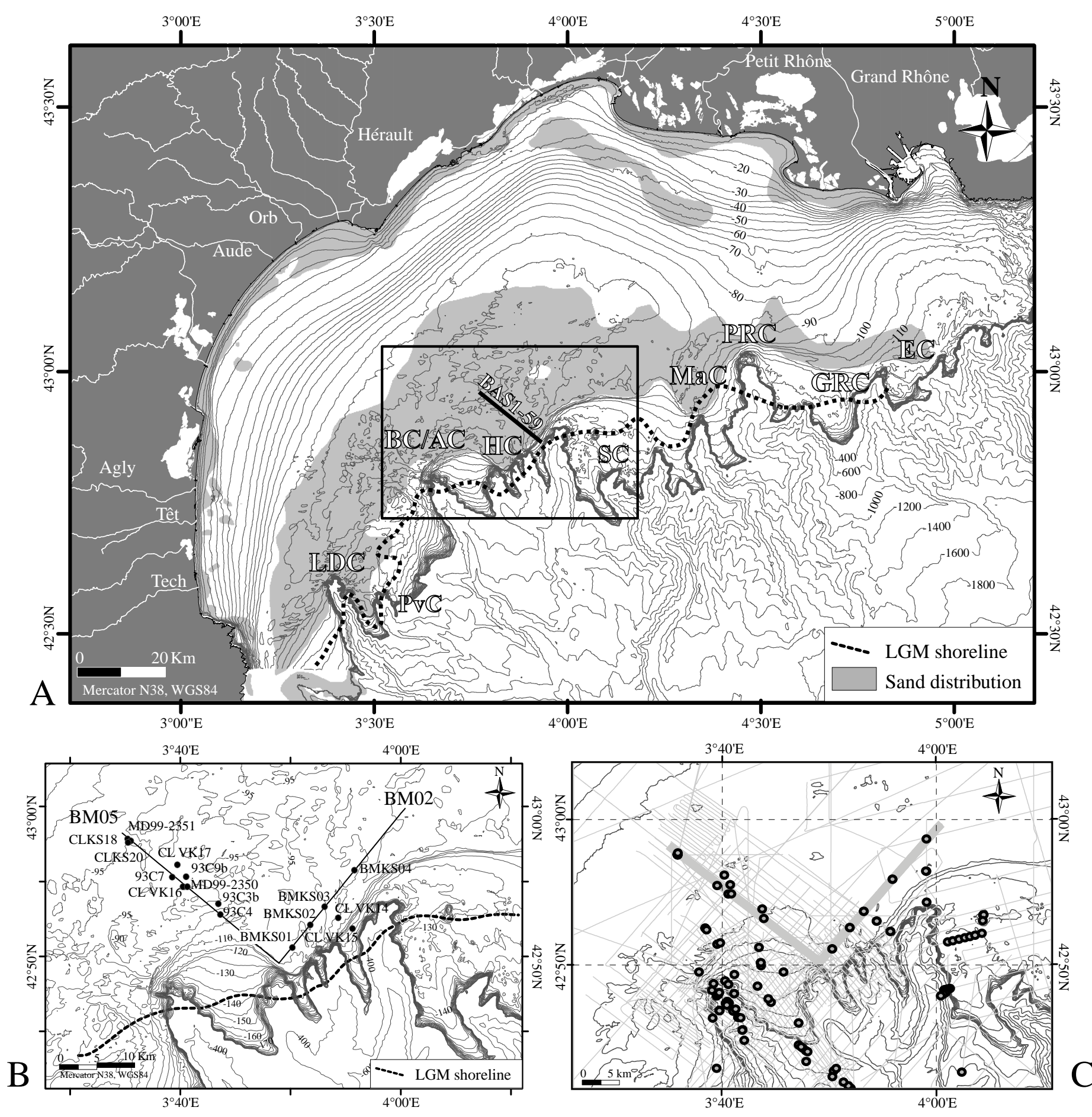

Fig.1

Bassetti et al. 

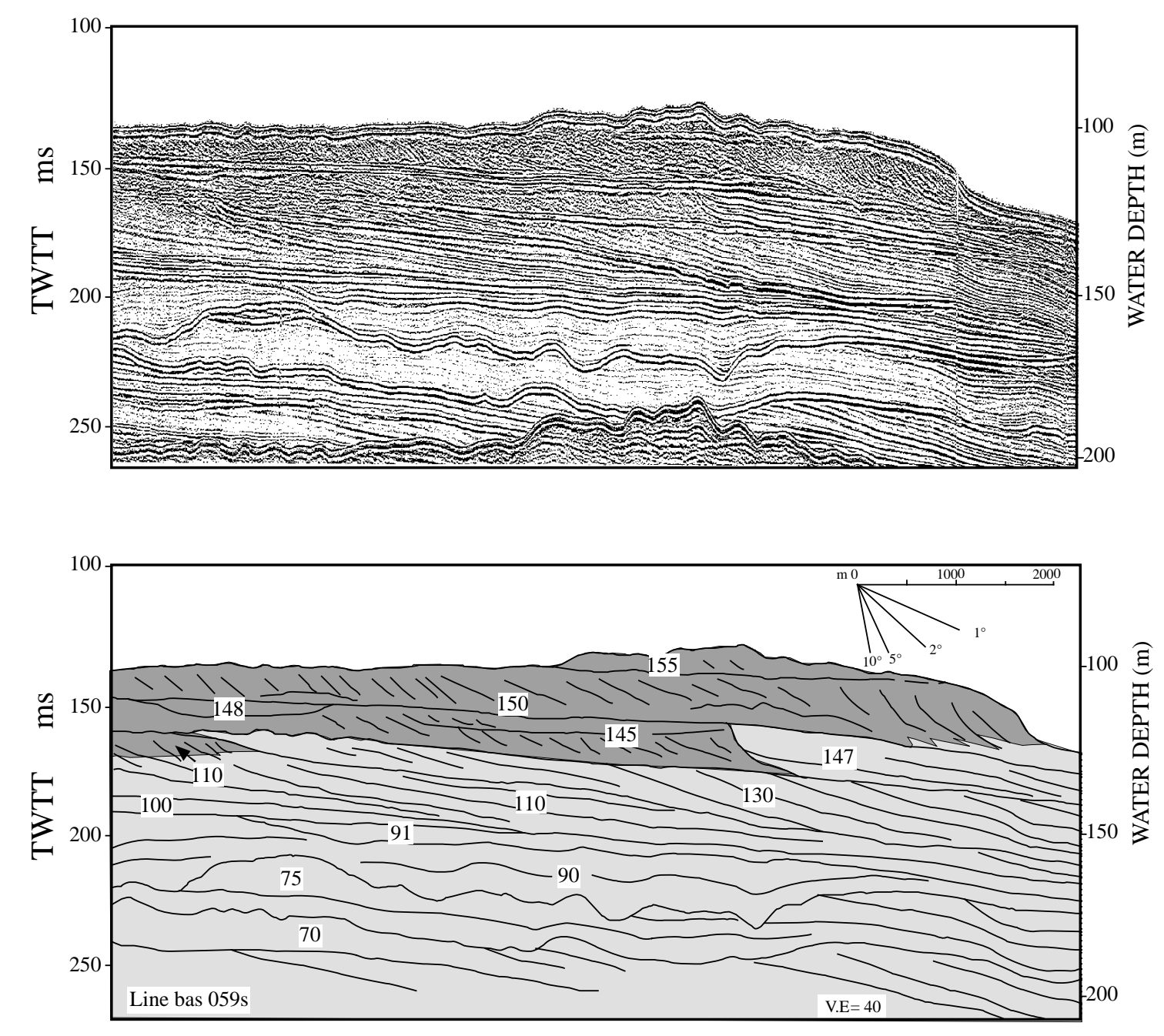

Fig.2

Bassetti et al. 
Critical

shear stress

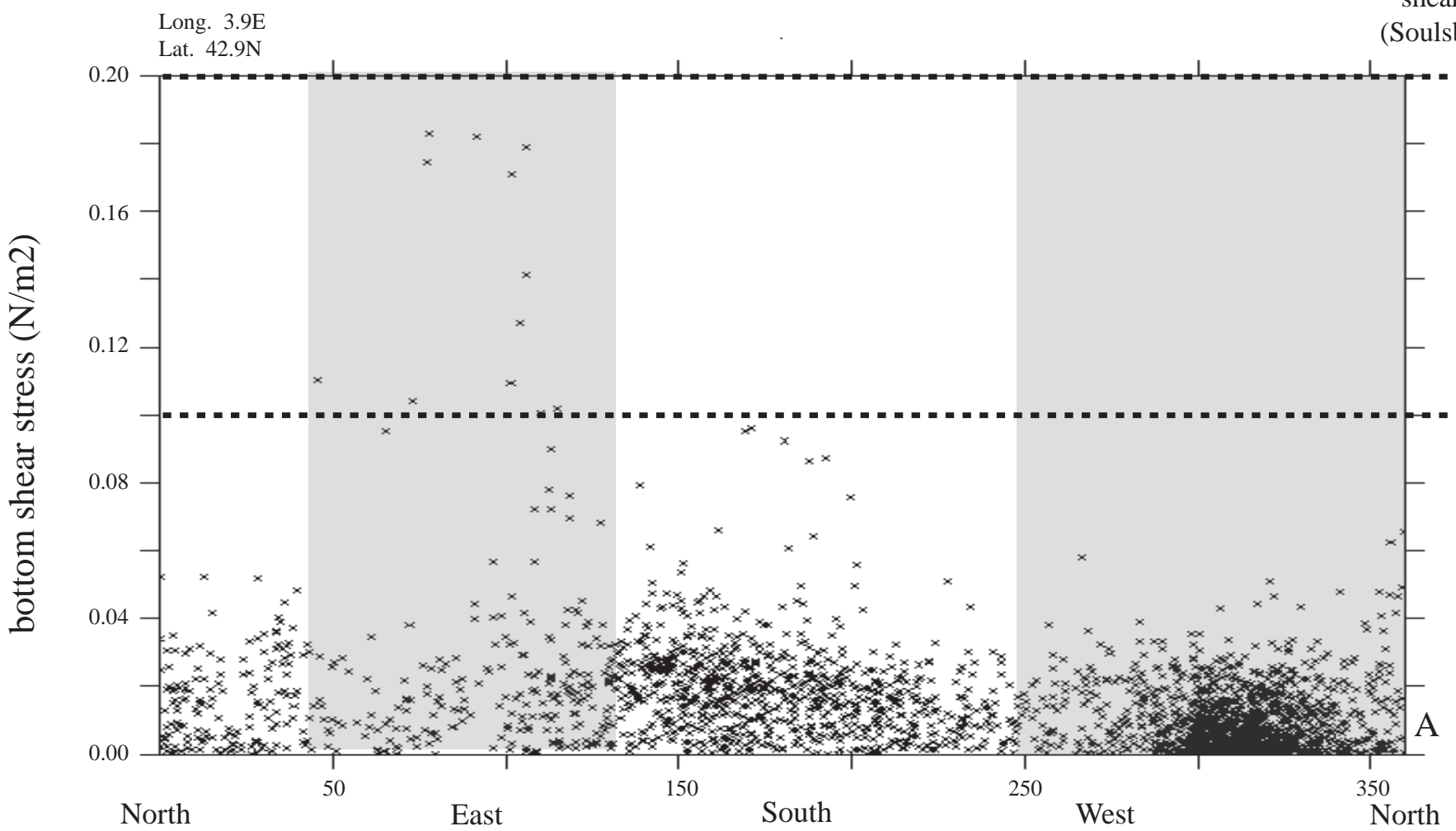

wind direction

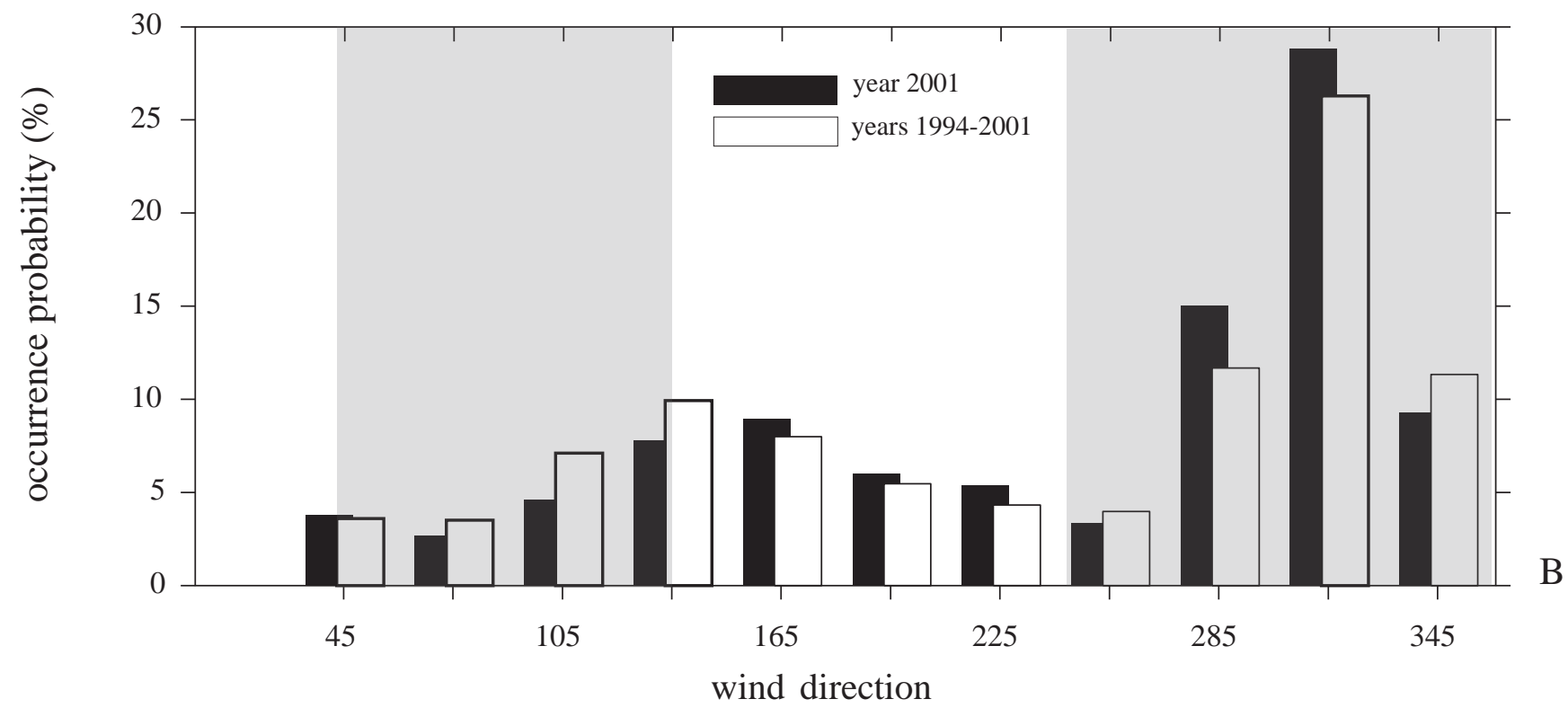

Fig.3

Bassetti et al. 


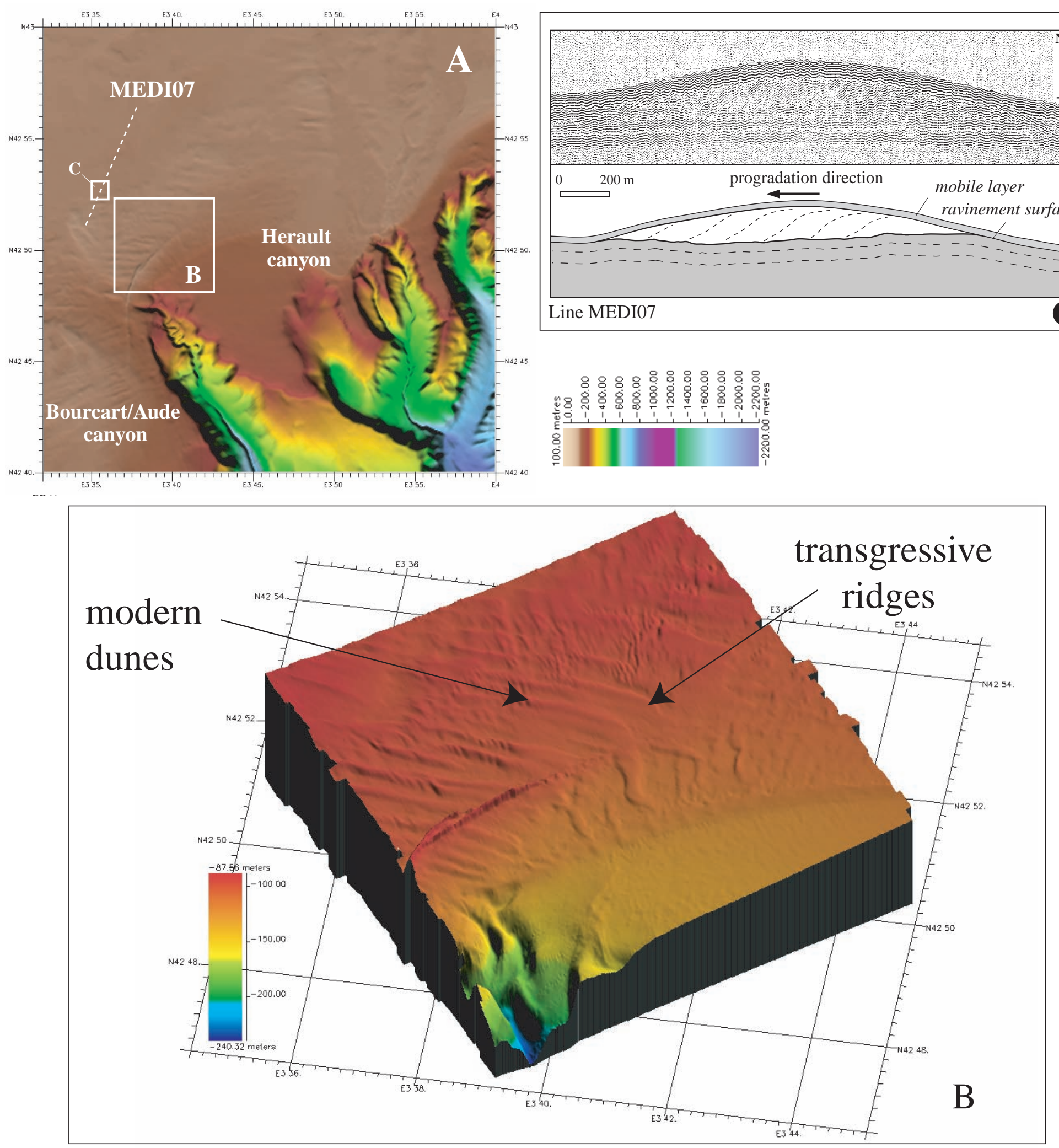

Fig. 4

Bassetti et al. 
A

${ }^{110} \mathrm{NW}$

$0 \quad 1 \mathrm{~km}$

SE

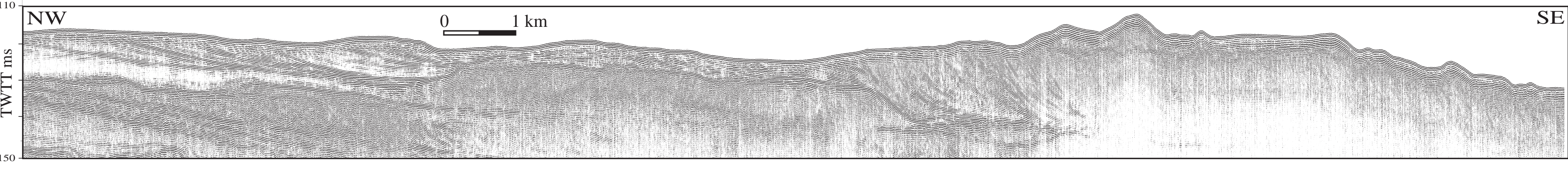

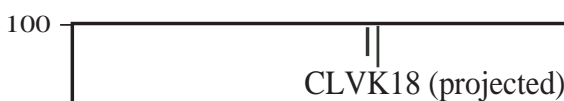

CLVK20

$\begin{array}{lllllll}1 & 1 & 1 & 1 & 1 & \text { Fig.7B }\end{array}$

U155 sand ridges

modern 'mobile' carpet

CLVK17 (projected) 93C9b (projected) MD99-2350 U160 Fig.7C

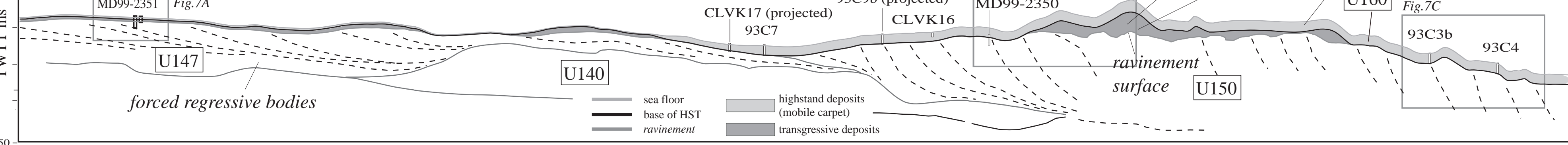

Line BM05

B

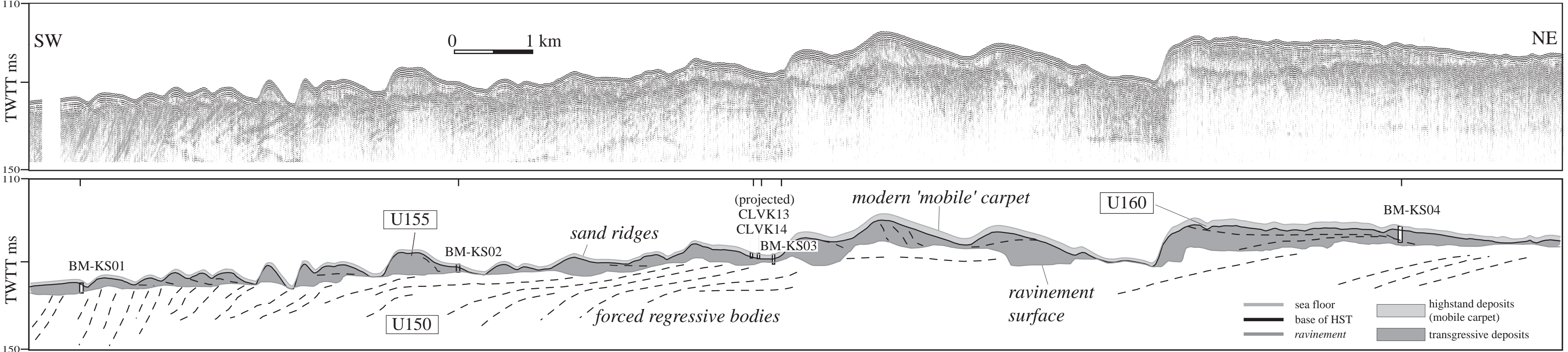

Line BM02

Fig.5

Bassetti et al. 


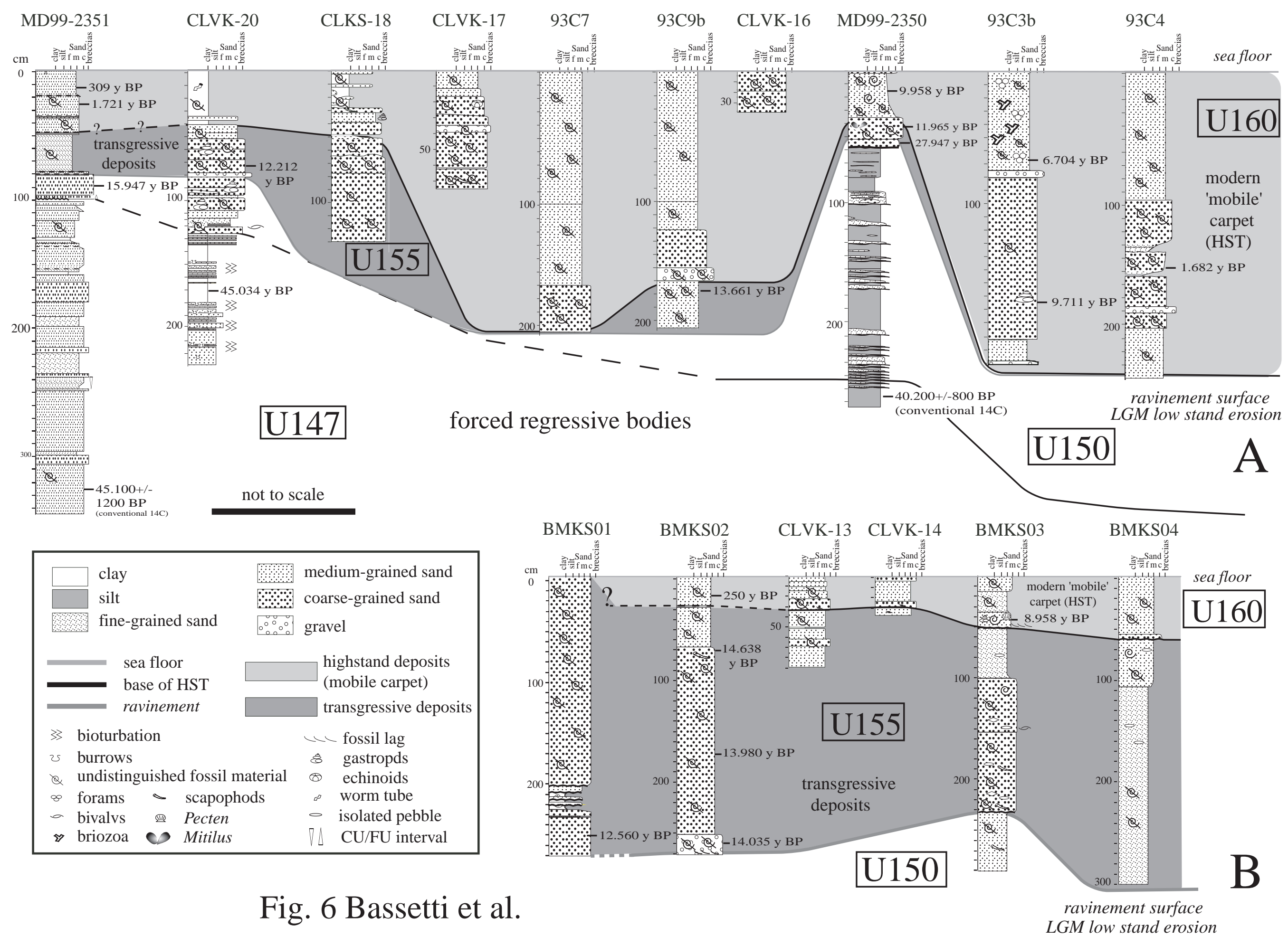




\section{Line BM05}

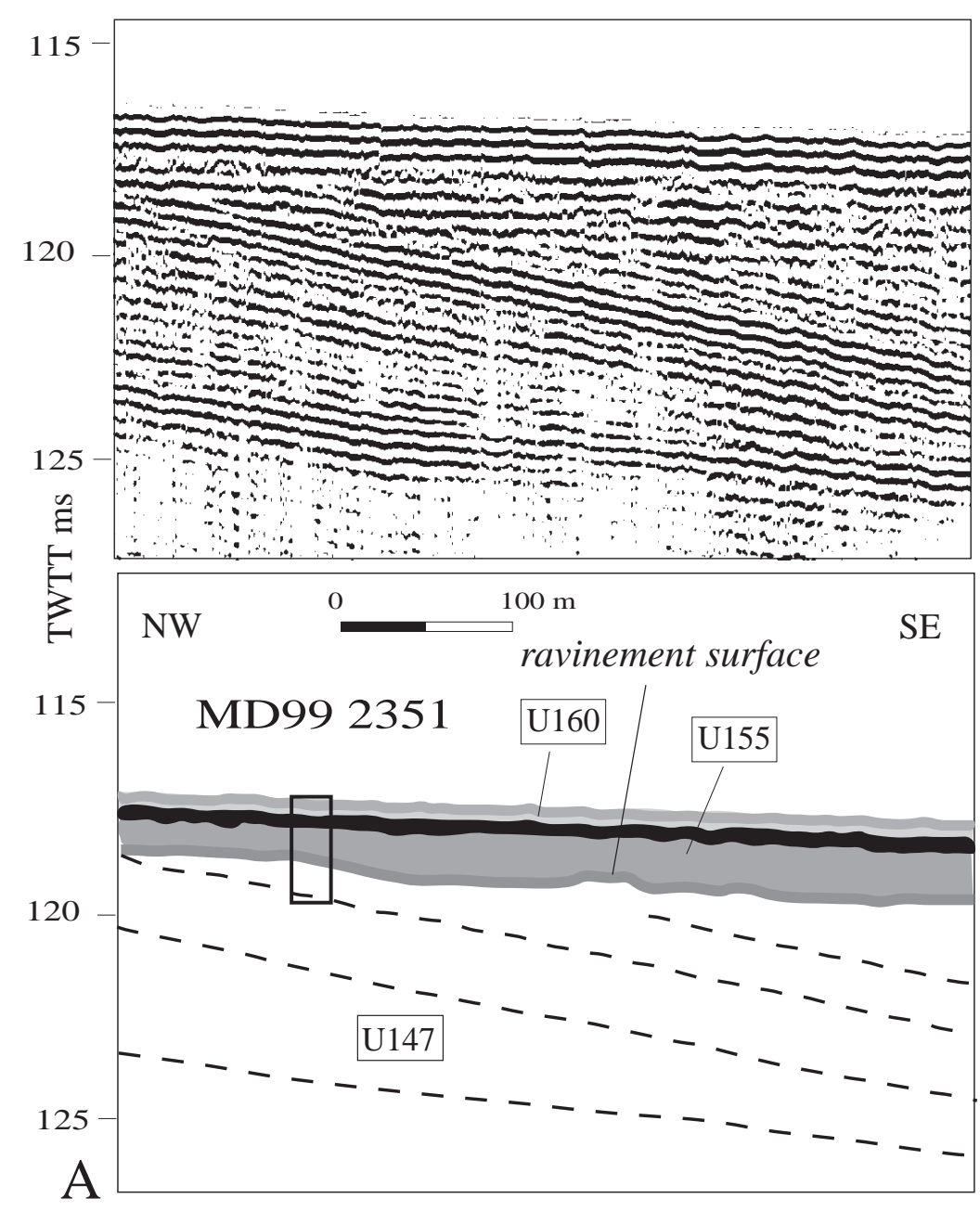

sea floor base of HST

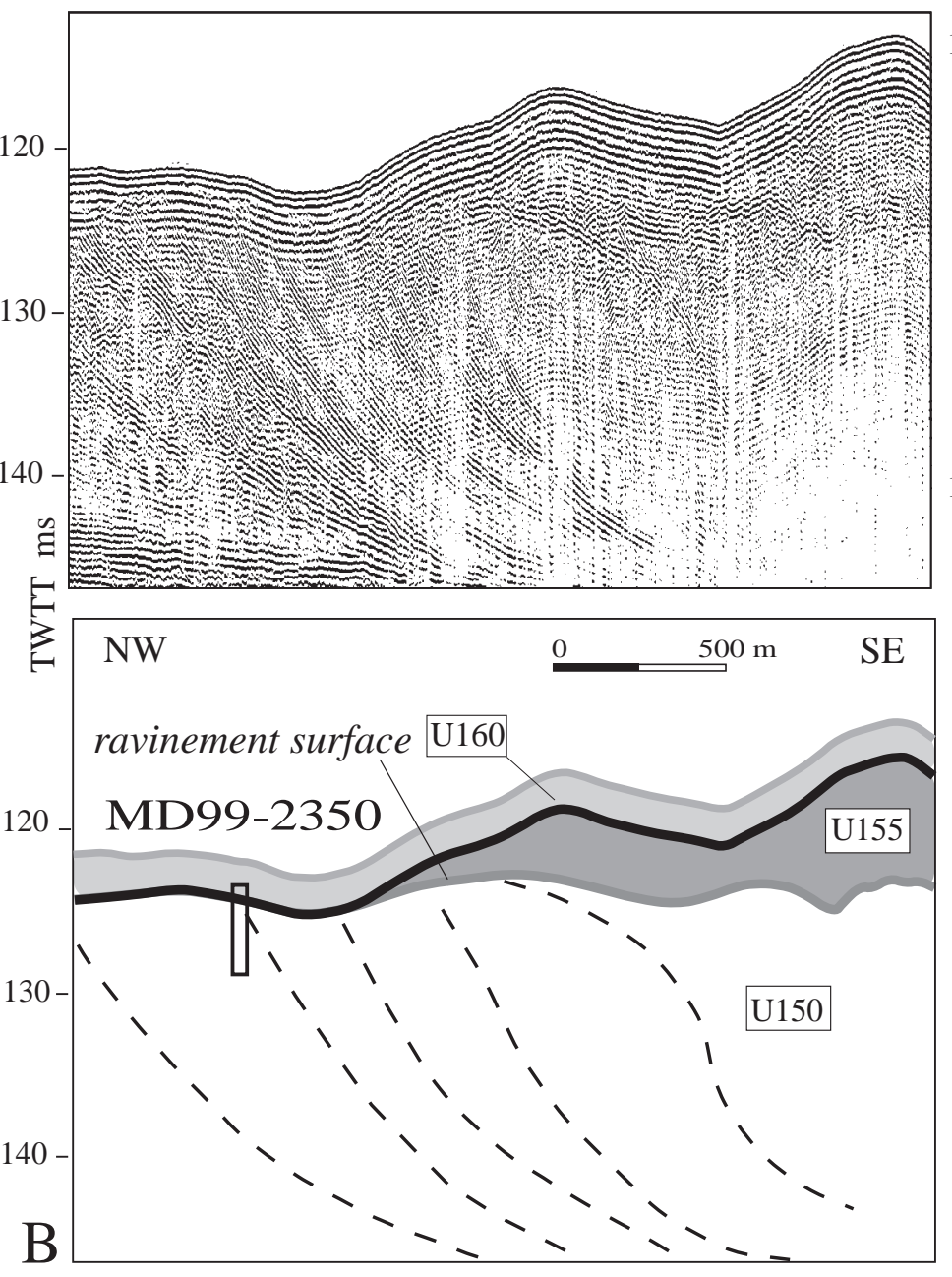

highstand deposits (mobile carpet)

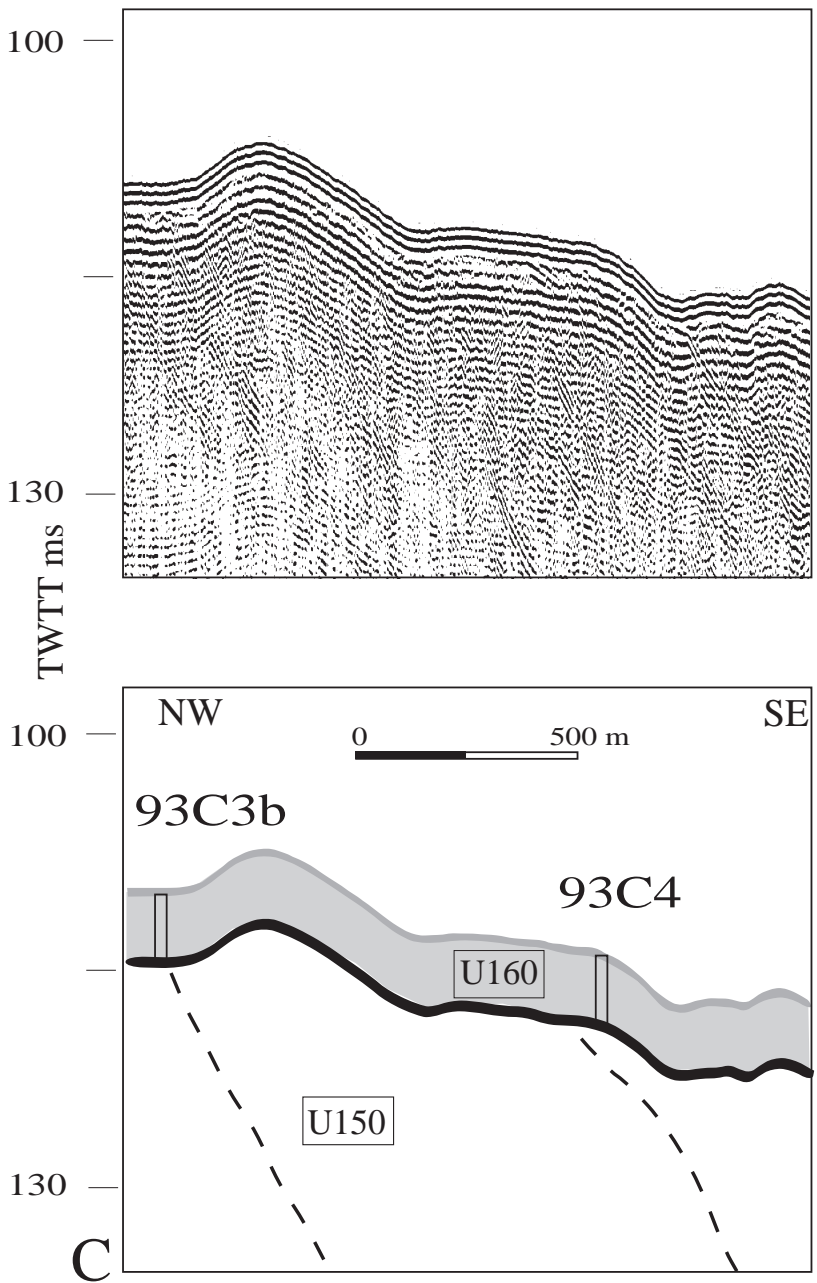

transgressive deposits

Fig. 7 Bassetti et al. 

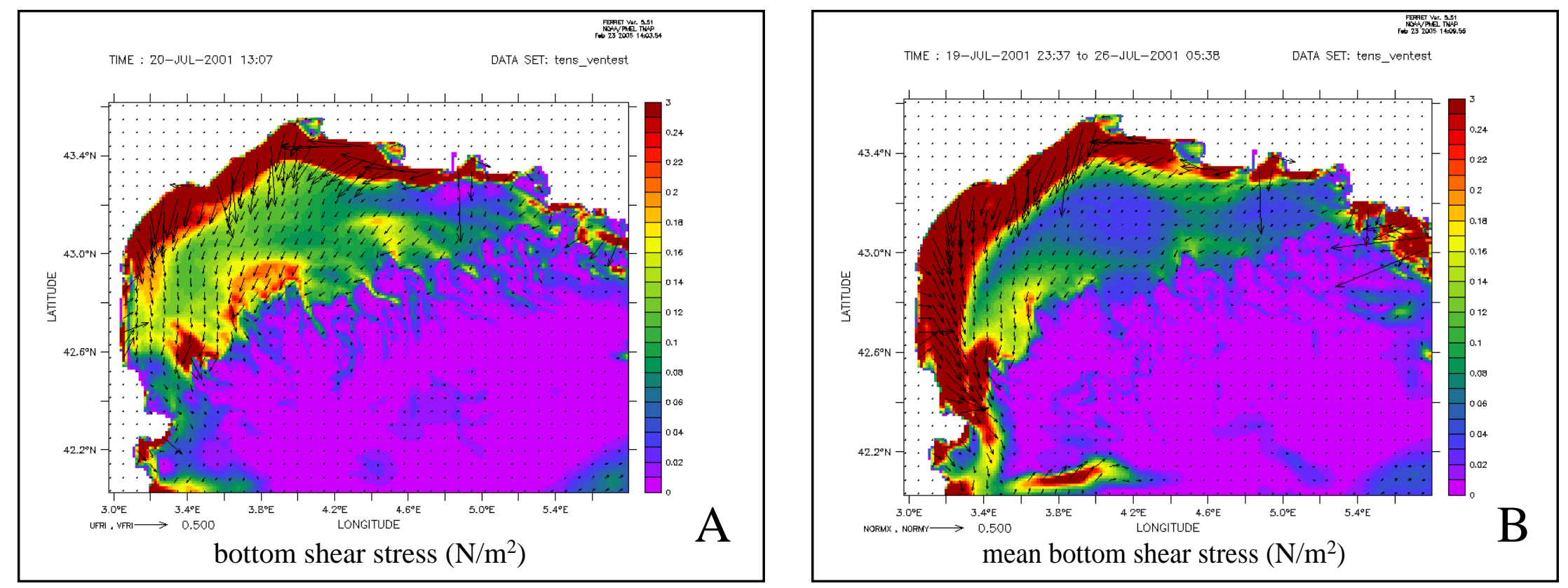

Fig.8

Bassetti et al. 


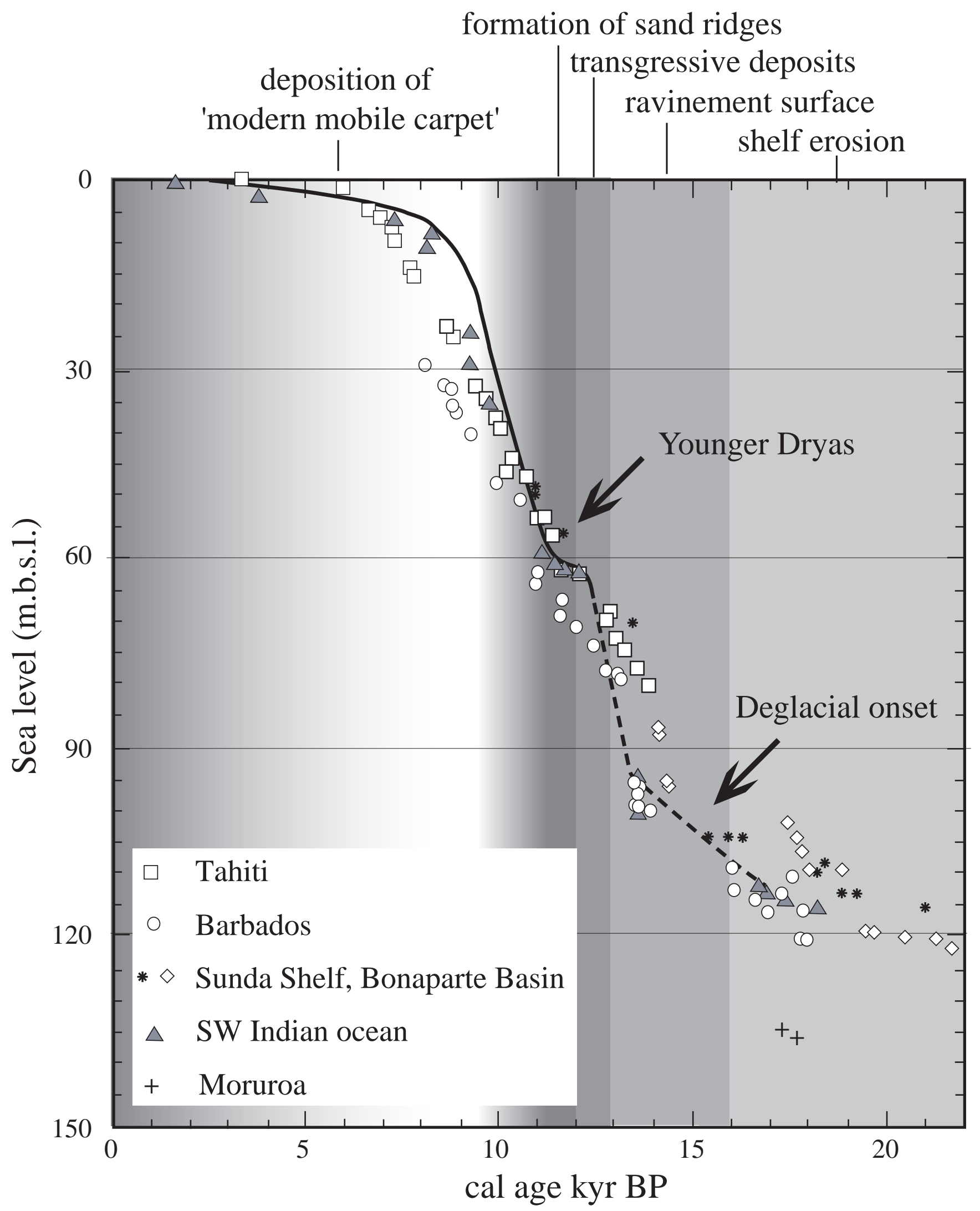

Fig. 9

Bassetti et al. 


\begin{tabular}{|c|c|c|c|c|c|c|c|c|c|c|c|}
\hline core & $\begin{array}{c}\text { sample } \\
\text { depth }(\mathrm{cm})\end{array}$ & $\begin{array}{c}\text { sample } \\
\text { weight } \\
\text { (mg) }\end{array}$ & lat ( N) & long ( E) & $\begin{array}{c}\text { water } \\
\text { depth } \\
\text { (m) }\end{array}$ & $\begin{array}{c}\text { Core } \\
\text { length } \\
\text { (m) }\end{array}$ & dated material & $\begin{array}{l}\text { dating } \\
\text { technique }\end{array}$ & $\begin{array}{l}\text { Conventional } \\
{ }^{14} \mathrm{C} \text { age (BP) }\end{array}$ & $\begin{array}{l}\text { calibrated age } \\
\text { (y BP) }\end{array}$ & $\begin{array}{c}\text { calibration } \\
\text { reference }\end{array}$ \\
\hline 93C3b & 70 & 30 & $42^{\circ} 55.32$ & $3^{\circ} 40.52^{\prime}$ & 96 & 1.96 & undet. bivalve & conventional & $6.305 \pm 45$ & 67.04-6.831 & $\begin{array}{l}\text { Hughen et al. } \\
\text { (2004) }\end{array}$ \\
\hline 93C3b & 161 & 93 & $42^{\circ} 55.32$ & $3^{\circ} 40.52$ & 96 & 1.96 & undet. bivalve & conventional & $9.085 \pm 45$ & $9.711-9.897$ & $\begin{array}{l}\text { Hughen et al. } \\
\text { (2004) }\end{array}$ \\
\hline 93C4 & 155 & 42 & $42^{\circ} 52.80$ & $3^{\circ} 43.68$ & 103 & 2.4 & undet. bivalve & conventional & $2.140 \pm 40$ & $1.682-1.797$ & $\begin{array}{l}\text { Hughen et al. } \\
\text { (2004) }\end{array}$ \\
\hline 93C9b-1 & 175 & n.a. & $42^{\circ} 55.32$ & $3^{\circ} 40.52$ & 96 & 1.96 & undet. bivalve & AMS & $12.290+/-80$ & $13.661-13.830$ & $\begin{array}{l}\text { Hughen et al. } \\
\text { (2004) }\end{array}$ \\
\hline BMK01 & 250 & 120 & $42^{\circ} 50.52$ & $3^{\circ} 50.13$ & 103 & 2.73 & Timoclea ovata & AMS & 12.560 & 13.914-14.108 & $\begin{array}{l}\text { Hughen et al. } \\
\text { (2004) }\end{array}$ \\
\hline BMKS02 & $25-27$ & 50 & $42^{\circ} 52.11$ & $3^{\circ} 51.78$ & 100 & 2,67 & $\begin{array}{l}\text { Caryophyllia } \\
\text { smithii }\end{array}$ & AMS & 250 & $6.014-6.578$ & $\begin{array}{l}\text { Hughen et al. } \\
\text { (2004) }\end{array}$ \\
\hline BMKS02 & 85 & 14 & $42^{\circ} 52.11$ & $3^{\circ} 51.78$ & 100 & 2,67 & $\begin{array}{l}\text { undet. bivalve } \\
\text { (articulated shell) }\end{array}$ & AMS & $12.980+/-60$ & $14.638-14.976$ & $\begin{array}{l}\text { Hughen et al. } \\
\text { (2004) }\end{array}$ \\
\hline BMKS02 & 160 & 35 & $42^{\circ} 52.11$ & $3^{\circ} 51.78$ & 100 & 2,67 & $\begin{array}{l}\text { undet. bivalve } \\
\text { (articulated shell) }\end{array}$ & AMS & $12.590+/-50$ & $13.980-14.111$ & $\begin{array}{l}\text { Hughen et al. } \\
\text { (2004) }\end{array}$ \\
\hline BMKS02 & 260 & 0,45 & $42^{\circ} 52.11$ & $3^{\circ} 51.78$ & 100 & 2,67 & $\begin{array}{c}\text { Corbula gibba } \\
\text { (articulated shell) }\end{array}$ & AMS & $12.690+/-60$ & $14.035-14.249$ & $\begin{array}{l}\text { Hughen et al. } \\
\text { (2004) }\end{array}$ \\
\hline BMKS03 & 50 & 0,33 & $42^{\circ} 53.33$ & $3^{\circ} 53.10$ & 98 & 2,83 & Veneridae sp. & AMS & $8.410+/-50$ & $8.958-9.090$ & $\begin{array}{l}\text { Hughen et al. } \\
\text { (2004) }\end{array}$ \\
\hline CLVK20 & $172-175$ & n.a. & $42^{\circ} 57.55$ & $3^{\circ} 35.56$ & 95 & 2.35 & ostracods & conventional & $39.710 \pm 720$ & 45.034 & $\begin{array}{l}\text { Bard et al. } \\
\text { (1998) }\end{array}$ \\
\hline CLVK20 & $68-74$ & n.a. & $42^{\circ} 57.55$ & $3^{\circ} 35.56$ & 95 & 2.35 & undet. bivalve & conventional & $10.875 \pm 120$ & $12.212-12.656$ & $\begin{array}{l}\text { Hughen et al. } \\
\text { (2004) }\end{array}$ \\
\hline $\begin{array}{l}\text { MD99- } \\
2350\end{array}$ & $14-17$ & 190 & $42^{\circ} 54.64$ & $3^{\circ} 40.63$ & 98 & 2.57 & Pitar rudis & AMS & 9.250 & 9.958-10.061 & $\begin{array}{l}\text { Hughen et al. } \\
\text { (2004 }\end{array}$ \\
\hline $\begin{array}{l}\text { MD99- } \\
2350\end{array}$ & 43 & n.a. & $42^{\circ} 54.64$ & $3^{\circ} 40.63$ & 98 & 2.57 & undet. bivalve & conventional & $10.715 \pm 60$ & $11.965-12.211$ & $\begin{array}{l}\text { Hughen et al. } \\
\text { (2004) }\end{array}$ \\
\hline $\begin{array}{l}\text { MD99- } \\
2350\end{array}$ & 240 & 1,01 & $42^{\circ} 54.64$ & $3^{\circ} 40.63$ & 98 & 2.57 & $\begin{array}{l}\text { Aequipecten } \\
\text { opercularis }\end{array}$ & AMS & $40.200+/-800$ & - & - \\
\hline $\begin{array}{l}\text { MD99- } \\
2350\end{array}$ & $53-54$ & 443 & $42^{\circ} 54.64$ & $3^{\circ} 40.63$ & 98 & 2.57 & Mytilus sp. & conventional & $24.170 \pm 140$ & 27.947 & $\begin{array}{l}\text { Bard et al. } \\
\text { (1998) }\end{array}$ \\
\hline $\begin{array}{l}\text { MD99- } \\
2350\end{array}$ & 99-101 & 13 & $42^{\circ} 54.64$ & $3^{\circ} 40.63$ & 98 & 2.57 & Nucula sp. & AMS & $42500+/-900$ & - & - \\
\hline $\begin{array}{c}\text { MD99- } \\
2351\end{array}$ & $15-17$ & 400 & $42^{\circ} 57.69$ & $3^{\circ} 35.59$ & 98 & 3.51 & Corbula gibba & AMS & 720 & $309-413$ & $\begin{array}{l}\text { Hughen et al. } \\
\text { (2004) }\end{array}$ \\
\hline $\begin{array}{c}\text { MD99- } \\
2351\end{array}$ & $22-25$ & 450 & $42^{\circ} 57.69$ & $3^{\circ} 35.59$ & 98 & 3.51 & $\begin{array}{l}\text { Acanthocardia } \\
\text { echinata }\end{array}$ & AMS & 2190 & 1721-1849 & $\begin{array}{l}\text { Hughen et al. } \\
\text { (2004) }\end{array}$ \\
\hline $\begin{array}{c}\text { MD99- } \\
2351\end{array}$ & 89-93 & 721 & $42^{\circ} 57.69$ & $3^{\circ} 35.59$ & 98 & 3.51 & Mytilus sp. & conventional & $13970 \pm 40$ & $15947-16320$ & $\begin{array}{l}\text { Hughen et al. } \\
\text { (2004) }\end{array}$ \\
\hline $\begin{array}{c}\text { MD99- } \\
2351\end{array}$ & $325-327$ & 23 & $42^{\circ} 57.69$ & $3^{\circ} 35.59$ & 98 & 3.51 & $\begin{array}{l}\text { mixed benthic } \\
\text { forams }\end{array}$ & AMS & $45100+/-1200$ & - & - \\
\hline
\end{tabular}

Table1: AMS and conventional ${ }^{14} \mathrm{C}$ datings of biogenic carbonate material 